\title{
Learning Economics by Servicing: a Mexican Experience of Service- Learning in Microenterprises
}

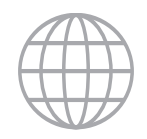

Alejandro Mungaray, Martín Ramírez-Urquidy, Michelle Texis, David Ledezma and Natanael Ramírez

\begin{abstract}
This paper presents an experience of a service learning program in underprivileged Microenterprises. An aspect that turns out to be original as compared to other contributions in literature is the explicit assessment of the impact of the program on the enterprises, since most of the related studies focus on evaluating the students experience and impact on learning derived from participation. The paper suggests that service learning programs with the participation of college students can play an important role both in supporting disadvantaged microenterprises and in providing meaningful learning experiences to students.
\end{abstract}

\section{Introduction}

The micro and small firms constitute an important feature of the industrial structure of most countries. In developing economies, this trend is reinforced by the overwhelming presence of microenterprises (MEs), defined as those enterprises employing up to 10 workers including the owner, and often linked to the informal sector run by modest entrepreneurs who engage in survival activities because they lack better options to make a living (Biggs et al., 1998). It is a fact that many governments have recognised the importance of such a large group of enterprises and are placing considerable emphasis on their promotion (Daniels and Mead, 1998). This applies also to some development multilateral agencies such as the World Bank, the Inter-American Development Bank, and the Economic Commission for Latin America and the Caribbean, which regard the promotion of these enterprises as a market-based strategy for poverty alleviation. 
Parallel to the ME debate, there are also voices arguing for the implementation of actions to improve the economics teaching of undergraduates (Becker and Watts, 2001 b; Becker, 2003), and attempts to take alternative teaching methods to classrooms in order to improve the atmosphere in which students learn economics (Becker and Watts, 1998). In this context, service-learning (SL) programmes in MEs based on the concept of community service (CS), can contribute to the preceding discussions. These programmes may be helpful not only to create excitement in learning economics and make meaningful the concepts reviewed in class through encouraging the students in communitarian activities, but also to promote economic education among poor entrepreneurs to help deal with their business affairs and thus lead to performance improvements.

This paper pursues two aims. First, it presents an experience of service-learning in underprivileged MEs, which includes the participation of economics students providing technical assistance to these enterprises as part of their training in microeconomics. Secondly, the paper explicitly assesses the impact of the Programme for Research, Assistance and Teaching on Small Enterprises on MEs. This provides an original contribution to the SL literature by showing that college students can play an important role in supporting disadvantaged microenterprises whilst also providing meaningful learning experiences for students. The first section presents a background on service-learning in Economics; the second reviews some of its applications in economics and the development of MEs. The next section introduces an experience of service-learning where students provide technical assistance in support of MEs, follows by a section that develops a method based on learning curves to assess the impact of the SL programme on the enterprise's performance. This is also intended to indirectly evaluate the ability of the students in the programme to change the reality of the MEs they worked with. This connects classrooms with real world environments and stimulates learning through the recognition of the usefulness of formal knowledge. The results are then discussed, and finally, a summary of the findings and the concluding remarks are presented.

\section{Service-learning in economics: a literature review}

A survey conducted by Becker and Watts (2001a) on teaching methods in economics suggested the predominance of chalk-talk: students passively listen to the teacher without any direct involvement in the process or any feedback from or exchange with the real world. Consequently, students get very limited experience of raising questions, looking for and using data, analysing real world situations with the support of the theories and instruments learned in class, discussing issues beyond the textbook or thinking critically. This standard practice in teaching and learning may be contrasted with the prescription for teaching that follows from 
Kolb's (1976) theory of experiential learning. Under this view, learning starts from a concrete experience, which is supported by observation and reflection. It then goes to a stage of formation of abstract concepts and generalisations explaining the phenomenon, and ends with a reinforcement of what has been learned through new concrete experiences, looking to apply the learning to as many cases as possible (see Figure 1). This 'learning cycle' may start at any of the four stages and runs continuously through them (Kolb, 1984).

Thinking like economists can be expressed in terms of Kolb's cycle as indicated in Figure 1 and entails identifying an interesting question (Stage I), gathering information, analysing it (Stage II), suggesting hypothesis (Stage III), forming conclusions and offering policy recommendations (Stage IV). This process does not occur in a lecture environment in economics. Students are usually required to analyse sets of equations and graphs from textbooks and to use the predetermined data provided. Questions are predetermined and hypothesis and evidence are provided to students (McGoldrick, 2002). In terms of Kolb's cycle the traditional teaching process in economics starts from abstract thinking, with the support of mathematical tools and general models (Stage III), to address a predetermined general question (Stage IV). Stage I, where students get inspired by experiences in the real world, and stage II, where they are motivated to look for and manage the data and to structure it in a meaningful to perform analysis, are frequently absent in economics training. Thus, economics schools train students in mastering standard economic models and techniques but not to think like economists because of the lack of relevant application and practice of concepts (Nowotny et al., 2001).

Figure 1: Kolb's learning cycle and economics thinking

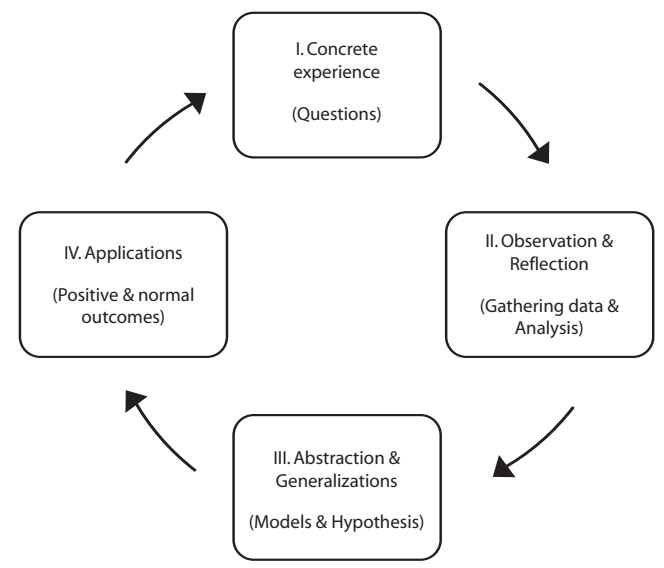


The stages in Kolb's model (I and IV) that are most neglected in traditional instruction in economics are, according to Dewey (1938), the stages in the process of learning that are most crucial to the development of understanding. Dewey also emphasises in his pedagogical theory and practice, that making things by routine rather than by conviction atrophies the scope of learning. He argues that a neglect of concrete experience tends to supplant the 'social spirit' with rigid institutionalism and individualism. That is, the form that teaching takes is not neutral with regard to the attitudes it fosters. Moreover he suggests that integration of concrete experience into the process of learning heightens students' motivation and interest by demonstrating the usefulness of abstractions.

Service-learning (SL) is an approach to learning-by-doing that highlights the social relevance of the work performed by universities. It can be regarded as an augmentation of the concept of Community Service (CS) with the inclusion of a learning component that may carry academic credits or may be part of a specific course requirement (Rhoads, 1997). The fundamental idea is that students learn and develop themselves through active participation in communitarian experiences organised and led by faculty, where they have the opportunity to apply the concepts and instruments recently acquired to help their community (Yates and Yuniss, 1999). More formally, Service Learning is a method of experiential learning that links the classroom with the local community, and requires students to spend time in volunteer service and relate their experiences to the educational knowledge they see in the classroom (McGoldrick, 1998). Dewey can be considered as a pioneer in integrating experiential learning into education and thereby constitutes a background for the SL pedagogy. He argued that the lessons learned when students are concerned for the welfare of others provided not only an educational stimulus but also an expansion of their horizons and encouragement to take responsibility for their fellow humans (Dewey, 1938).

McGoldrick (2002) suggests that participants in SL activities apply knowledge by testing academic learning; synthesising knowledge by bringing together past and present learning, giving coherence to students' studies; critically think and analyse by learning to distinguish what is and is not important in the unfiltered context of the real world; learn about cultural diversity by learning with, from and about people of other races, ages, economic means and competences; develop values through first-hand interaction with community issues; and learn inductive reasoning by using the specific as a starting point for hypothesizing and theorizing.

Service-learning as a methodology highlighting active participation in communities is consistent with sociological streams of learning. Wenger (1998) considered that learning is a social process formed by the experience derived from 
our participation in the world, which has important implications for our understanding and perspective of it. Learning as a participation process seeks to reconcile theories of social structure assigning priority to institutions, rules and regulations, and theories of situated experience which consider learning as an integral part of our daily life. He emphasises the existence of an intermediate process by which we can experience the world and our commitment to it as something meaningful associated with the formation of communities, which is on the grounds of social practice theories; and individuals' social training highlighted by theories of identity.

\section{Some applications of Service Learning in economics and MEs development}

There are some interesting and diverse applications of $S L$ in the economics field. One is McGoldrick (1998) who provides a framework to analyse $S L$ issues in a class which studies women and gender issues in economics. The students were given an option to volunteer in an emergency shelter for women. The author describes the students' experience using the Kolb learning cycle and argues that the students' reaction to the class was positive. One student acknowledged that she would never have been exposed to the issue of homelessness without this experience and faculty members who viewed a poster session delivered by the students were impressed.

Another experience is the Business Conditions and Economic Analysis (BCEA) programme developed at the University of Richmond. At an initial stage of implementation, the BCEA group conducts domestic and global macroeconomic analysis and industry studies to support the portfolio decisions of student fund managers. At a more mature stage, the programme includes a web-based publication for disseminating macroeconomic forecasts and special topic articles written by students enrolled in BCEA and the Student-Managed Investment Funds programme. The BCEA group prepares a 'Global Overview and Economics Conditions' report, delivered monthly to all members of the SMIF programme, that covers key macroeconomic data as well as developments in specific industries and sectors. Formal written and oral presentations of economic forecasts and analysis provide measures of success in student learning. At the end of the day, courses in the programme provide a logical inventory of skills, competencies and learning objectives aimed at a capstone experience (Dolan and Stevens, 2005).

Simmons (2003) reports an additional experience at the Economics Department of the College of Business at Oklahoma City University, where a class was created to study the 'Economics of Poverty'. The class incorporated students from all majors and combined basic economic theory, a survey of literature pertinent to poverty and an 
experiential learning experience. During the last phase, students volunteered in a variety of assignments, which exposed them to individuals and families living on the margins of society. Simmons reports a profound impact on the students and argues for the power that SL has to change lives. In addition, it reports that this experience unexpectedly generated dramatic influences on the students in the class, reaching different students, and enabling them to 'live' poverty rather than simply reading and listening about poverty. All this turned this course into one of the most successful offered in many years in that academic community.

Some experiences of service-learning in microenterprises in Latin American countries have been previously reported (Stroud 2005). However, few specific details are available about these programmes, and discussion of their impact has only referred to potential impacts on students, teaching and the curriculum. The first case constitutes the Students in Free Enterprise (SIFE) worldwide programme, a $S L$ programme encouraging the formation of a class to be offered at the college level, where participants engage in community service activities to promote the free enterprise system. Stephenson (1997) reports an experience linking the SIFE programme with the Small Business Institute (SBI) in-depth student consulting projects, which are especially well suited to this programme. The SBI Programme provided consultancy to 6,000 small business owners via 18,000 to 20,000 graduate and undergraduate students a year. A measure of programme success was the extent to which the programme aided small businesses that needed help to produce reports demonstrating profit, income and employment increases whilst being unable to afford private sector consultants. The evaluation of this programme reported success as measured by student satisfaction, client satisfaction, and perceived impact on employment, revenues, skills and enhancement of the national SBI programme. A second programme of SL in small businesses, the Campus Service-Learning Center (Peters et al., 2006) focused on project development, logistical support and assessment for business students who participated in on-site human resource management projects. The evaluation focuses on students' satisfaction and does not provide evidence of the impact of the projects on enterprises.

Although this review of SL practices in economics related to MEs makes no claim to be exhaustive, it does suggest that this kind of practice is not very widespread and that its impacts on the micro-enterprises has not previously been systematically evaluated.The SL experiences evidence three trends: the increasing interest and inclusion of SL methodologies in economic education; the focus in the students' experiences and faculty teaching experience rather than the community impact assessment; and the view of SL only as a teaching-learning methodology rather than viewing it also as a strategy contributing to development. 


\section{A Mexican experience of SL supporting MEs}

Since 1945 Mexico's Constitution has incorporated Community Service (CS) as a requirement for students in higher education to obtain a degree in all disciplines. CS has been a strategy to combat urban and rural poverty, and to extend the benefits of science and technological development to the disadvantaged sectors of the Mexican Society (Mungaray and Sanchez, 2003). This fact allows for the use of the SL method in Mexican higher education, giving senior students the opportunity to apply their profession, access their social context and develop a feeling of affection for their community and the value of solidarity. This concept inspires the Programme for Research, Assistance and Teaching on Small Enterprsies, which was created as a Community Service programme in 1999 at the Autonomous University of Baja California, in the northwest state of Mexico bordering with California. The main objectives of the Programme are to deliver Business Development Services (BDS) in situ at no cost to underprivileged enterprises, conduct research on small firm development, and build up a model of teaching and learning for students in the field of economics, business, management and surrounding disciplines. From the perspective of higher education, the programme constitutes a SL approach of teaching, encouraging the students' professional learning, experience and entrepreneurial skills; and a research-action method of doing research while providing care, and also making research pertinent (Mungaray, 2002).

Students enrolled in the programne attend the microenterprises for a 12-week period and work as consultants, developing a complete programme of data collection, processing and analysis that ends up in a report on the performance of the enterprise to be provided to the entrepreneurs. They provide in situ assistance, offering an on-call response to specific problems confronted by the entrepreneurs. While students engage with the entrepreneurs, they transfer knowledge including economic and business concepts (particularly in relation to marketing, accounting, finance and cost techniques), management and technical skills, and information on regulation and institutional environment. That is, they build human capital within the MEs in which they are working.

The students' consultancy is provided within a framework of instruments and tools that formalise the relation between the entrepreneurs and the university. This framework characterises the enterprise profile, guides the data collection and report generation, and defines indicators to assess the productive units. There are three main tools: an Agreement, a Diagnosis and Schedule of Indicators. The Agreement is a written document which formalises the participation of the MEs in the programme. The Diagnosis is a comprehensive survey applied by the students at the beginning of the assistance phase which constitutes a baseline to start intervention and includes preliminary information about the enterprise. The 
Schedule of Indicators is a record of the operations of the enterprise and indicators monitored on a daily or weekly basis. These include sales, output, costs, usage of inputs, and wages, among other variables, which are then used to construct an enterprise financial and economic profile. At the end of the assistance period, students analyse the ME data, use a set of economic and financial techniques to assess the enterprise and produce a report on the status of the enterprise, recommendations for improvement, and microfinance feasibility, which is signed by the university (Mungaray et al., 2007).

\section{Measuring the effectiveness of the SL programme}

\section{The model}

The estimation is based on Berndt (1991), who proposes a method of integrating the learning curve ( $\mathrm{LC}$ ) to the cost function to deal with returns to scale through the use of a two-input Cobb-Douglas production function and the derivation of the cost function by using cost minimisation. This procedure yields equation 1 (see the Appendix), which was estimated for each of the MEs.

$\ln c_{t}=\beta_{0}+\beta_{1} \ln n_{t-1}+\beta_{2} \ln y_{t}$

The variables, $c_{t}, n_{t-1}$ and $y_{t}$ are average cost at $t$ period, cumulative output up to but not including period $t$, and $y_{t}$ is period $t$ output, respectively. Parameters $\beta_{0}, \beta_{1}$ and $\beta_{2}$ are respectively the intercept of the function, the elasticity of learning and the scale parameter.The effects of learning are captured by the parameter $\beta_{1}$, which is expected to be negative for learning to take place $\left(\beta_{1}<0\right)$, and is manifested by downward shifts in the average cost function. The scale parameter can be used to test the hypothesis regarding constant or non-constant returns to scale, by the execution of a t-test under the null hypothesis $\beta_{2}=0$ for constant, versus the alternative hypothesis $\beta_{2} \neq 0$ for non-constant returns to scale. Scale effects are represented by movements along the function in $\ln y_{t}-\ln c_{t}$ space. Learning is verified by looking at the sign of the parameter $\beta_{1}$ as first approach. The statistical analysis of the equation can be conducted by determining the individual significance of using $\beta_{1} t$-tests, or by analysing the overall significance of the model in terms of F-test, which test jointly the parameters in the multiple regression under the null hypothesis $\beta_{0}=\beta_{1}=\beta_{2}=0$, and verify that the estimates of $\beta_{1}$ exhibit the theoretically expected signs. The equation is estimated by using ordinary least squares.

Including scale in the LC solves for an important factor affecting average costs, but there are many other variables that can also affect it, such as general economic conditions and supply and demand shocks which affect input prices mostly, and the level of ME activity, all of them having the possibility of impacting in the short 
run independently of scale and learning. Other elements that can affect costs, particularly in self-employment MEs or even in larger ones, are the owners' and workers' personal feelings or conditions such as health, mood and motivations among others, often categorised as the X-Efficiency. These potential effects on average cost through impacts on productivity and efficiency are unobserved in this study since these data are not available. This introduces a specification problem, with the risk that estimates are biased. However, there are mitigating factors. First, the effects of unobserved variables may be picked up by the scale variable that is included. Secondly, if the presumed excluded variables are uncorrelated with the included regressors then the bias implied by omitting variables would not exist (Cameron and Pravin, 2005), which would be the case if those variables affect only costs and not output and cumulative output as assumed above.

\section{The data of the MEs}

The data are derived from a sample $(n)$ of 80 MEs operating in industries classified in food products. The productive units in the sample are self-employed performing survival activities, low value-added with reduced human capital and out of the state regulations, so they are a subset of the informal economy. Table 1 shows the basic figures of the MEs under study. The data were collected on a daily basis by the students enrolled in the programme directly from the sample of enterprises in the state of Baja California, on the northern border of Mexico, during the period 2001-05.

Table 1: Summary of indicators of the MEs in the Sample

\begin{tabular}{|c|c|c|c|c|}
\hline \multicolumn{5}{|c|}{ Economic indicators } \\
\hline Sample (n) & $\begin{array}{l}\text { Value added per } \\
\text { working day (\$) }\end{array}$ & $\begin{array}{c}\text { Value of } \\
\text { assets per } \\
\text { Microenterprise }(\$)\end{array}$ & $\begin{array}{c}\text { Workers per } \\
\text { Microenterprise }\end{array}$ & $\begin{array}{c}\text { Value added } \\
\text { per worker } \\
(\$)\end{array}$ \\
\hline 8025.00 & 949.91 & 1.89 & 13.23 & \\
\hline \multicolumn{5}{|c|}{ Schooling } \\
\hline No education & Elementary & Junior High & $\begin{array}{l}\text { Technical } \\
\text { education }\end{array}$ & High School \\
\hline 13 & 26 & 26 & 11 & 4 \\
\hline $16.25 \%$ & $32.5 \%$ & $32.5 \%$ & $13.75 \%$ & $5 \%$ \\
\hline \multicolumn{5}{|c|}{ Vintage } \\
\hline Up to 1 year & $\begin{array}{l}\text { More than } \\
1 \text { to } 5 \text { years }\end{array}$ & $\begin{array}{l}\text { More than } \\
5 \text { to } 10 \text { years }\end{array}$ & $\begin{array}{c}\text { More than } \\
10 \text { years }\end{array}$ & \\
\hline 26 & 29 & 18 & 7 & \\
\hline $32.5 \%$ & $36.25 \%$ & $22.5 \%$ & $8.75 \%$ & \\
\hline
\end{tabular}


The enterprises average 1.89 workers, generate a daily value added per enterprise of $\$ 25.00$ in real terms, and have an average value of assets by enterprise of US\$949.91 respectively. The daily value added per worker is US\$13.23. Converting these figures on a yearly basis working five days a week, the added value per enterprise and perworker would be about US\$6,500.00 and US\$3,175.00 respectively.

The human capital profile of the enterprises is low since 16.25 per cent have no schooling at all, whereas 65 per cent have up to junior high. The remaining MEs exhibit technical education (13.75 per cent) and only 5 per cent high school. Most of the MEs in the sample (68.75 per cent) have been existence for five or less years. Only 9 per cent of the MEs had been in business for 10 or more years.

In order to benchmark the sample of MEs we use the regional minimum wage (MW) and the average remuneration in terms this MW. According to the National Institute of Statistics, Geography and Informatics (INEGI), the Mexican official source, the daily minimum wage in the state was US\$4.25 in 2005. According to computations based on INEGI data, the average remuneration weighted by population in the state is 4.45 times higher than this minimum wage. An extrapolation of this average remuneration on a yearly basis results in average remuneration per person of US\$4,539, about 25 per cent lower than the value added created by the average enterprise in the region and 43 per cent higher than the average value added per worker in the sample, according to Table 1.Thus, we conjecture that the level of productivity of the MEs in the sample is considerably lower than the state average. This provides more information about the microenterprises under study as compared with the overall productive sector in the state, thus suggesting that they are in need of support programmes. However, a more rigorous treatment of this issue would require an effort beyond the scope of this work.

\section{Discussion of results}

The econometric results are reported in Table 2. A total of 53 MEs exhibited a negative relation between average cost and cumulative production over the internship period, which is represented by $\beta_{1}<0$, as suggested by theory, for learning to take place. The F-statistic for those cases reports the overall significance of the model, supporting the learning hypothesis for these cases. Learning is also verified by testing the significance of the parameter $\beta_{1}$ under the null hypothesis $\beta_{1}$ $=0$. This procedure reports that 24 of the MEs (30 per cent) showed learning (a negative and statistical significant relation between $c_{t}$ and $n_{t}$ over the period) at 10 per cent statistical significance. It is also observed that some of the regressions exhibit a positive relation between $c_{t}$ and $n_{t}$, but only 12 of these (15 per cent) were statistically significant at 5 or 10 per cent. The balanced results favour the 


\begin{tabular}{|c|c|c|c|c|c|c|c|c|c|c|c|c|}
\hline$\subset$ & $\stackrel{\Xi}{\sim}$ & 으 & นึ & nn & $\stackrel{\bullet}{\circ}$ & $\stackrel{\infty}{\sim}$ & $\stackrel{\mathcal{F}}{\mathcal{F}}$ & $\mathcal{F}$ & เి & ம & $\stackrel{\bullet}{\sim}$ & $\stackrel{N}{N}$ \\
\hline ப & 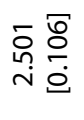 & 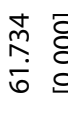 & 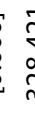 & 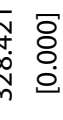 & $\begin{array}{l}\text { 능 용 } \\
\text { ஸ் }\end{array}$ & 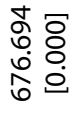 & 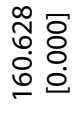 & 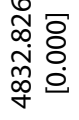 & $\begin{array}{l}\text { ஸ } ீ \\
\infty \\
\infty \\
\infty\end{array}$ & 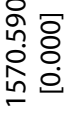 & 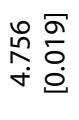 & 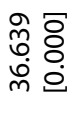 \\
\hline 方 & $\begin{array}{l}\circ \\
\infty \\
0 \\
\end{array}$ & 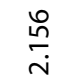 & & 옴 & ஓे & 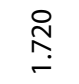 & $\underset{-}{\bar{f}}$ & 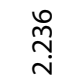 & $\frac{\stackrel{\infty}{m}}{i}$ & 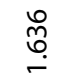 & ָㅗㅀ & 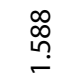 \\
\hline $\begin{array}{l}\tilde{\sigma} \\
\tilde{\simeq}\end{array}$ & $\frac{\text { nn }}{\frac{1}{0}}$ & $\begin{array}{l}\stackrel{0}{n} \\
\\
0\end{array}$ & & ֻু & $\frac{\stackrel{n}{m}}{\stackrel{0}{i}}$ & $\begin{array}{l}\text { ๖े } \\
\text { О̆ }\end{array}$ & $\begin{array}{l}0 \\
\infty \\
\infty \\
0\end{array}$ & ूू & 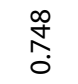 & $\begin{array}{l}\text { m } \\
\text { ô } \\
0\end{array}$ & $\underset{ }{\stackrel{n}{0}}$ & ฮั \\
\hline$\tilde{n}^{2}$ & 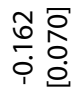 & 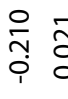 & 先 & 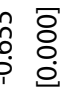 & 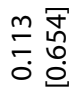 & 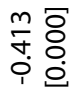 & 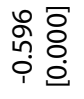 & 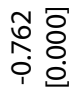 & 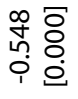 & $\begin{array}{l}m \overline{8} \\
0 \\
\infty \\
0 \\
0 \\
1 \\
\end{array}$ & 六 & 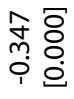 \\
\hline $\bar{n}$ & 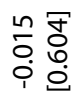 & 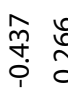 & 8 & 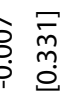 & 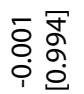 & 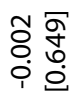 & 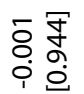 & $\begin{array}{l}\text { 용 } \\
\text { 응 } \\
\text { 잉 }\end{array}$ & 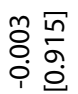 & $\begin{array}{l}\bar{\delta} \\
\overline{8} \\
0 \\
0 \\
0 \\
i \\
0\end{array}$ & $\begin{array}{l}\text { nू } \\
\text { ஸे } \\
\text { ọ } \\
\end{array}$ & 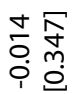 \\
\hline$\infty^{0}$ & $\begin{array}{l}\infty \\
\stackrel{\infty}{\circ} \\
\stackrel{\infty}{\circ} \\
-\end{array}$ & $\hat{\hat{o}}$ & ? & 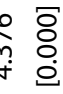 & $\begin{array}{l}\infty \\
\infty \\
\stackrel{0}{\circ} \\
\stackrel{0}{0}\end{array}$ & 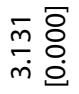 & $\begin{array}{l}\text { 용 } \\
\text { m̊ } \\
\text { in }\end{array}$ & $\begin{array}{l}\infty \\
\stackrel{\circ}{\circ} \\
\stackrel{\circ}{\circ} \stackrel{0}{\circ}\end{array}$ & $\begin{array}{l}\text { 용 } \\
\text { n̊ } \\
\text { n் }\end{array}$ & 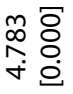 & $\begin{array}{l}\text { ¿ } \overline{8} \\
00 \\
0 \\
0\end{array}$ & 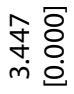 \\
\hline$\cdot-$ & $\bar{\gamma}$ & $\stackrel{*}{\text { \& }}$ & & $\stackrel{m}{\sim}$ & $\forall$ & $\stackrel{\text { I }}{+}$ & 우 & $\hat{f}$ & $\stackrel{\infty}{+}$ & g & 으 & in \\
\hline$\simeq$ & f & เి & & 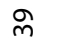 & $\stackrel{\bullet}{\sim}$ & $N$ & $\stackrel{\mathrm{m}}{\mathrm{m}}$ & Ln & $\stackrel{N}{N}$ & ১্ & $\stackrel{+}{+}$ & \\
\hline ᄂ & 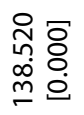 & 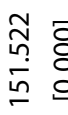 & & 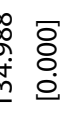 & 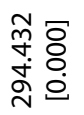 & $\begin{array}{l}\text { 엉 } \\
\text { 응 } \\
\stackrel{\sim}{\sim}\end{array}$ & 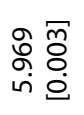 & $\begin{array}{l}\overline{\hat{x}} \delta \\
m \\
\infty \\
\infty\end{array}$ & 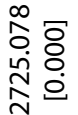 & 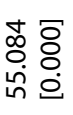 & 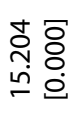 & 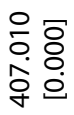 \\
\hline 方 & 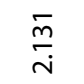 & $\frac{\bar{m}}{\bar{i}}$ & & 菅 & $\begin{array}{l}\stackrel{\emptyset}{\emptyset} \\
\text { mִ }\end{array}$ & $\stackrel{m}{\stackrel{m}{ }}$ & $\stackrel{N}{\infty}$ & $\frac{\text { กิ }}{\text { กั }}$ & ڤั & 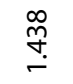 & $\frac{\infty}{\check{N}}$ & $\frac{\bar{j}}{\dot{v}}$ \\
\hline $\begin{array}{l}\tilde{\sigma} \\
\underset{\sim}{\sim}\end{array}$ & $\begin{array}{l}\text { ণิ } \\
\text { ᄋุ }\end{array}$ & $\begin{array}{l}\text { o } \\
\infty \\
0\end{array}$ & & $\underset{\substack{n \\
\infty}}{0}$ & $\begin{array}{l}\bar{\alpha} \\
\text { ọ }\end{array}$ & $\begin{array}{l}\text { } \\
\stackrel{0}{0} \\
\infty \\
0\end{array}$ & 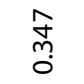 & $\begin{array}{l}0 \\
\stackrel{0}{0} \\
0\end{array}$ & ুু & $\begin{array}{l}\text { రั } \\
\text { นุ' } \\
0\end{array}$ & $\stackrel{\substack{n\\
}}{0}$ & $\begin{array}{l}\infty \\
\text { ŏ } \\
\text { ’ }\end{array}$ \\
\hline ص & 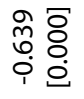 & 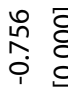 & 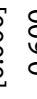 & \begin{tabular}{ll}
3 & $\overline{8}$ \\
0 & 8 \\
\hdashline & 0 \\
& 0
\end{tabular} & 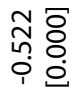 & 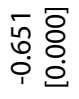 & 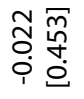 & 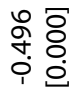 & 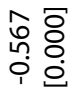 & 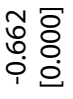 & $\begin{array}{l}m \\
\infty \\
\infty \\
0 \\
0 \\
0 \\
1\end{array}$ & 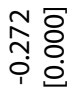 \\
\hline $\bar{n}$ & 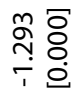 & 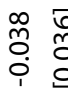 & 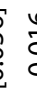 & 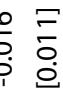 & 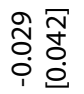 & 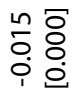 & $\begin{array}{l}\text { 용 } \\
\circ \circ \\
\circ \\
\end{array}$ & 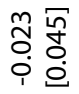 & 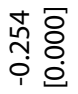 & 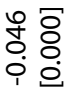 & 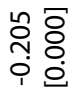 & $\begin{array}{l}\infty \\
\bar{\circ} \\
\\
\end{array}$ \\
\hline$\infty^{0}$ & 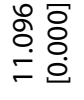 & $\begin{array}{l}\text { N̂ } \\
\text { mn } \\
\text { nn }\end{array}$ & s & 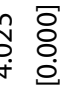 & $\begin{array}{l}\stackrel{\circ}{\mathrm{O}} \\
m \\
m \\
m\end{array}$ & 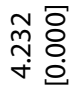 & $\begin{array}{l}\simeq 8 \\
\simeq 8 \\
\mp 8 \\
\end{array}$ & 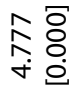 & $\begin{array}{l}\text { 용 } \\
\text { in }\end{array}$ & 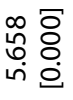 & $\begin{array}{l}\infty \\
0 \\
\text { in } \\
\text { in } \\
\text { in }\end{array}$ & $\begin{array}{l}\frac{o}{\dot{y}} \delta \\
\text { mे } \\
m\end{array}$ \\
\hline 2 & $*$ & ก & I & $n$ & $\stackrel{*}{*}$ & Ln & $\underbrace{*}$ & & ${ }_{\infty}^{*}$ & $\sigma$ & 으 & $\mp$ \\
\hline
\end{tabular}




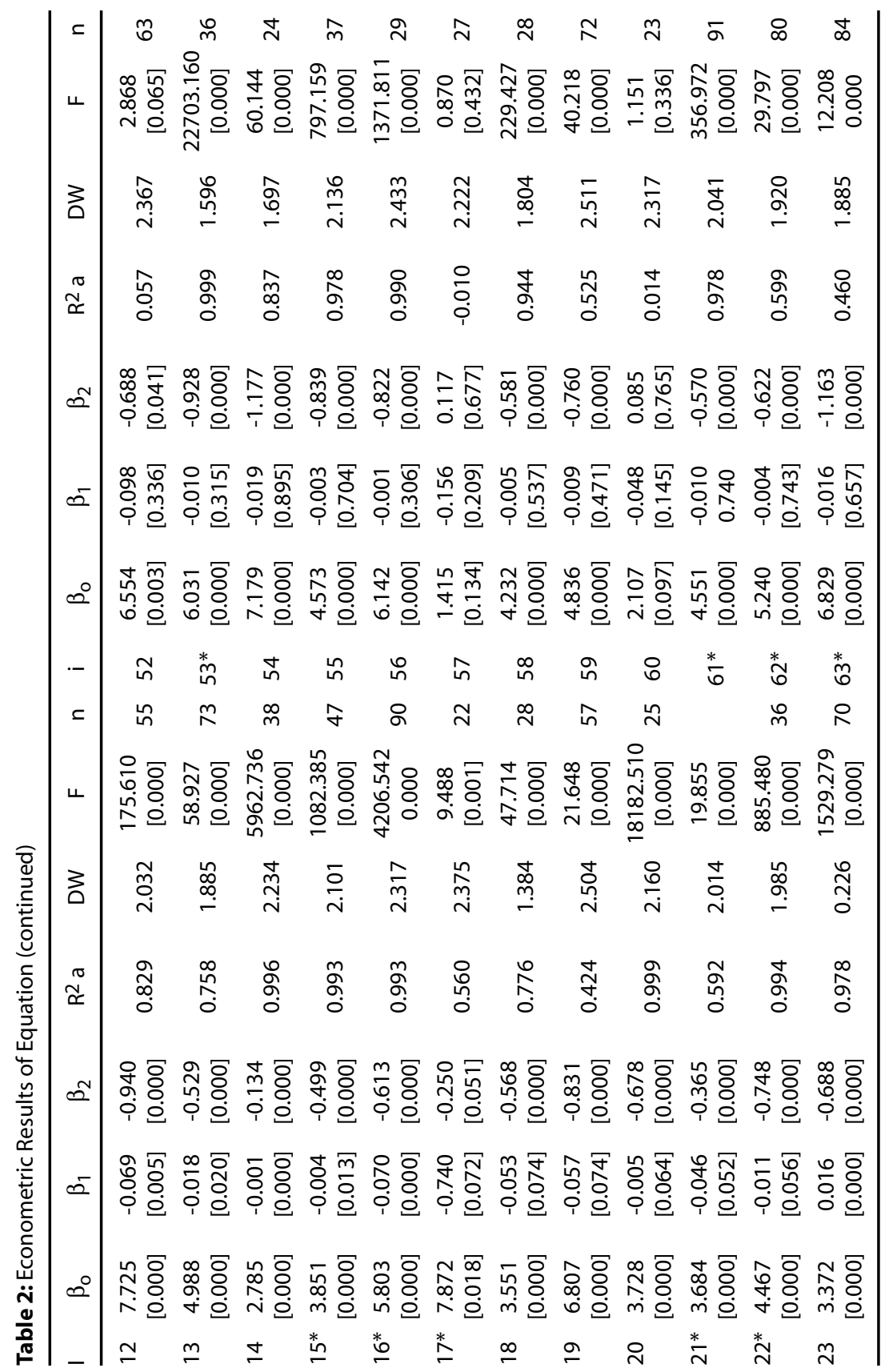




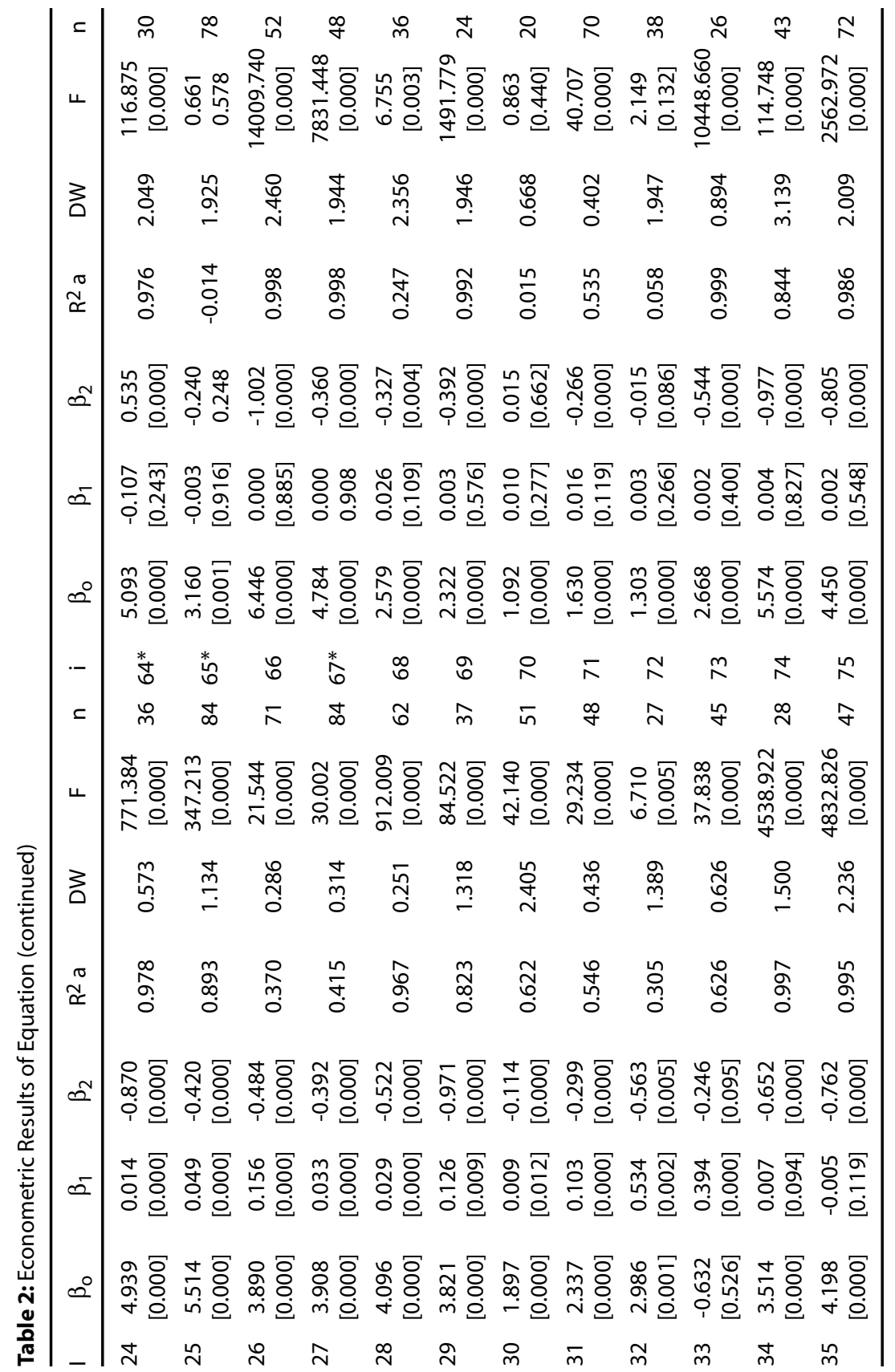




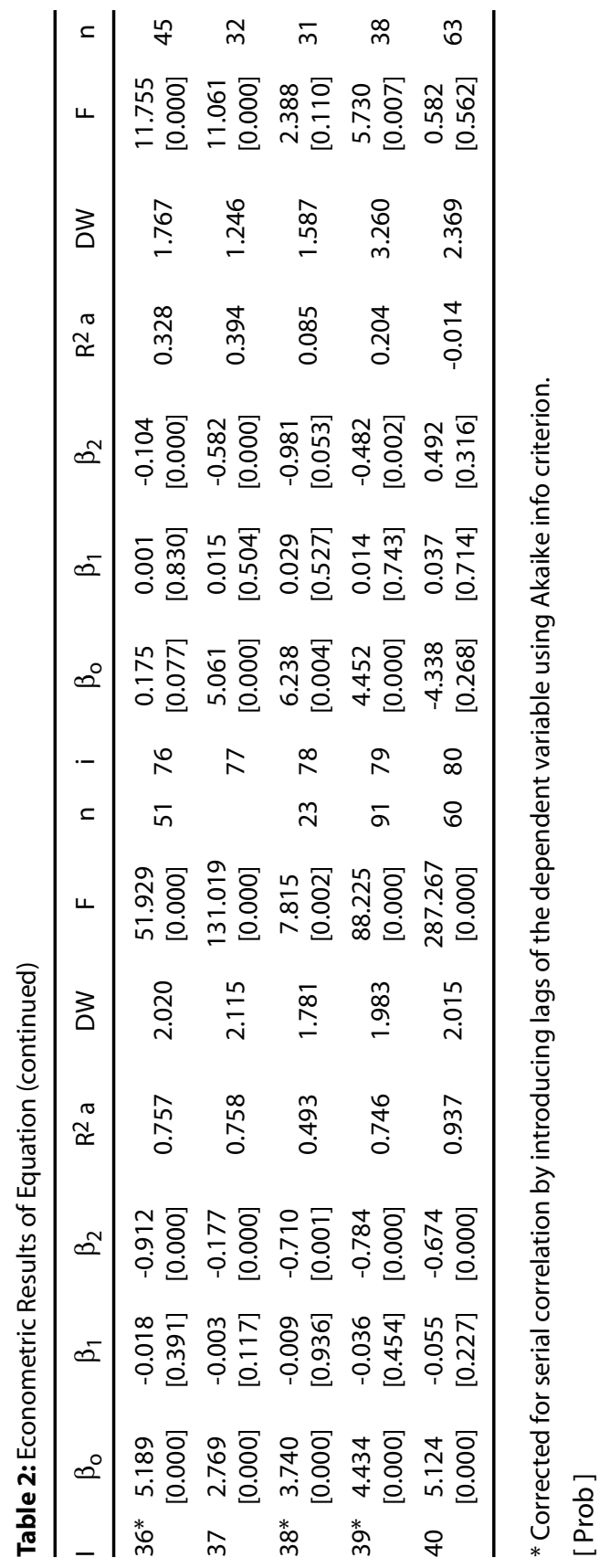


hypothesis that the SL programme where students in the final year of their careers get involved in communitarian activities, technically assisting MEs, can contribute to their performance.

The econometric results of the learning model show a great dispersion of the statistics related to the regressions for the $80 \mathrm{MEs}$, including the number of observations employed in each of them. Data vary significantly according to the available information in the range between 23 and 91 daily observations. This divergence is due to several case-specific factors related to the MEs and the students doing the internship. Some MEs would work twice or three times a week, diminishing the possible time series data available. Other enterprises may have accepted to participate in the programme and then refused to provide data, exited the market or switched to a different activity, showed intermittent business, or the consultant students drop the project and the associated academic units. The explanatory capacity of the variables included $\left(n_{t}, y_{t}\right)$ measured by the statistic adj. $\mathrm{R}^{2}$ is also heterogeneous among the enterprises' regressions but in general it indicates a good fit. The $\mathrm{F}$ tests indicate that the overall model is significant at the 5 per cent level. The statistic DW for serial correlation suggests the rejection of the null hypothesis in the majority of the regressions. Those cases failing to reject the hypothesis of serial correlation were corrected by introducing lags of the dependent variable as regressors using the Akaike Info Criterion. The coefficient associated to the scale $y_{t}$ is significant for most of the cases, except for two where the hypothesis of constant return to scale was not rejected. These results are presented in Table 2.

There is much to argue about the reasons explaining the benefits to microenterprises derived from engaging with the students. Factors other than the SL programme may have contributed to the learning and average cost reduction in the MEs.

Perhaps one of the most convincing factors operating emerges from economic theory and regards the well-established principle of marginal returns, as follows:

$$
\frac{\partial y\left(x_{0}, z_{0}\right)}{\partial x}>\frac{\partial y\left(x_{1}, z_{0}\right)}{\partial x} \text { provided that } x_{0}<x_{1}
$$

The inequality suggests that returns at the margin in terms of output from increasing input $x$, ceteris paribus $\left(z_{0}\right)$, are higher the scarcer is the input. If we call learning $x$, then the transfer of knowledge from students close to finishing a degree in economics to modest, untrained and low-educated entrepreneurs having low $\mathrm{x}$, may bring large returns in terms of average cost reduction and learning consequences in the enterprise. These knowledge spillovers may take the form of basic principles of economics, unsophisticated ideas, advice, hints, technical 
aspects, including motivational stimulus, and some general economics education to improve decision making.

A somewhat similar reasoning applies in situations where the entrepreneurs are engaged full time in a routine of production-distribution in their business, and have no time left to do the planning and think about how to improve their business to raise profitability. It may be that entrepreneurs have reached a point where no new ideas are generated due to fatigue. The consulting services by the students focused naturally on the planning and serve as a refreshing flow of ideas complementing the experience of the entrepreneurs and showing good results in the firm's performance.

Some cases exhibited a positive relation between average cost and cumulative production. These cases may be associated with misleading consulting, but also with factors not accounted for in the estimated model, like technology changes and labour turnover and its impact on learning. Other factors may emerge due to the nature of the enterprises under study whose management lies basically with the owner, who may get sick, or suffer from depression or fatigue, with consequences for the performance of the enterprise. An alternative explanation is that the consultancy encouraged the enterprise to aim for quality improvements that entailed more expensive inputs.

This impact assessment methodology can be improved by several means. First, an improved method may include other alternative variables related to the Mes' performance in addition to average cost such as sales, profits and some qualitative variables on the way the community perceives the programme. On the other hand, the implicit specification of variables related to the intensity of the consultancy, such as the effort of the students, the tracking and analysis of the advices given over the assistance period, the number of hours dedicated to the enterprises, to mention a few, may enrich the method greatly. This is part of a future research agenda.

\section{Concluding remarks}

This paper examined the hypothesis that SL programmes with the participation of college students can play an important role both in supporting disadvantaged microenterprises and in providing meaningful learning experiences to students. In stressing its point, the article introduced the Programme for Research Assistance and Teaching on Small Enterprises, a model of teaching economics to undergraduates founded on the SL approach, which also constitutes a public effort supporting unprivileged groups. The paper did not measure learning of students directly; rather it provided an assessment of the efficacy of the SL programme in achieving its goal. The advance proposed in this paper was approaching learning of the students 
enrolled in the programme through the assessment of the enterprises' performance during the assistance period as measured by the learning curve model. The results derived from the application of the method reports evidence favouring the hypothesis that the SL programme contributed to the Mes' cost performance. Roughly one third of the enterprises in the sample exhibited a negative relation between average cost and cumulative output over the internship period.

It is also argued that students' learning is fostered by a method of teaching which is based on well established theories of learning. Evidence of the helpfulness of students' advice to MEs may be considered as one, rather demanding, way of measuring their learning.

The normative implications of this analysis are particularly important to developing countries, whose resource constraints require policy innovation designed to improve the efficiency of resource allocation. Service-learning programmes such as Programme of Research Assistance and Teaching of Small Enterprises have the potential to benefit developing countries in three ways: by increasing the social returns of public resources devoted to education; complementing industrial policy with specific programmes suitable to the increasing ME sector; and by highlighting the social relevance of learning in higher education institutions. For the economics discipline, SL provides a complementary teaching strategy that can motivate learning through experiences that make a social contribution.

\section{Appendix}

Learning curves (LC) are often estimated using the standard found in literature:

$$
c_{t}=c_{0} n_{t-1}^{\alpha_{c}} e^{u_{t}}
$$

where $c_{\mathrm{t}}=$ Average cost at time period,$c_{\mathrm{o}}=$ Average cost at the initial period, $n_{\mathrm{t}-1}=$ Cumulative output produced up to (but not including) time period $t, \alpha_{\mathrm{c}}=$ Elasticity of average cost with respect to cumulative volume (typically negative) and $u_{\mathrm{t}}=$ Stochastic disturbance term. An inconvenience with equation A.1 is its assumption of constant returns to scale, which often is not the case for data.

Berndt (1991) proposes a method of integrating the $L C$ to the cost function to deal with returns to scale. Assuming the two-input Cobb-Douglas production function on A.2:

$y_{t}=A_{t} x_{1 t}^{\alpha_{1}} x_{2 t}^{\alpha_{1}}$ 
Where $A_{t}$ is the parameter reflecting the state of knowledge and returns to scale $(r)$ are $r=\alpha_{1}+\alpha_{2}$. For the two-input case, total costs $\left(C_{t}\right)$ may be written generally as in A.3:

$$
C=p_{1} x_{1}+p_{2} x_{2}
$$

The dual approach of cost minimisation leads to the derivation of the cost function in equation A.4:

$$
C_{t}=\frac{y_{t}^{\frac{1}{r}} p_{1 t}^{\frac{\alpha_{1}}{r}} p_{2 t}^{\frac{\alpha_{2}}{r}}\left(\alpha_{1}+\alpha_{2}\right)}{A_{t}^{\frac{1}{r}} \alpha_{1}^{\frac{\alpha_{1}}{r}} \alpha_{2}^{\frac{\alpha_{2}}{r}}}
$$

We can set the cost function in A4 in a more tractable way by assuming and applying the natural log to obtain the equation in A.5.

$\ln C_{t}=\ln k+(1 / r) \ln y_{t}+\left(\alpha_{1} / r\right) \ln p_{1 t}+\left(\alpha_{2} / r\right) \ln p_{2 t}$

In order to integrate learning in the cost equation, it assumed in $k$ that $A_{t}=n_{1}-\alpha_{c}$, where the state of knowledge in time period $t$ now is defined as the cumulative level of output up to period $t$. This leads to a new definition of $k$, as $k^{\prime}=$ $r\left(\alpha_{1} \alpha_{1} \alpha_{2} \alpha_{2}\right)^{-1 / r}$ and to the cost function arranged to include learning (A.6).

$$
\ln C_{t}=\ln k^{\prime}+\left(\alpha_{c} / r\right) \ln n_{t-1}+(1 / r) \ln y_{t}+\left(\alpha_{1} / r\right) \ln p_{1 t}+\left(\alpha_{2} / r\right) \ln p_{2 t}
$$

Assuming that input prices $p_{1 t}$ and $p_{2 t}$ are fixed, and subtracting from both side of the equation, we are left with the average cost functionwhich differentiates from the typical LC in equation $\mathrm{A} 1$ by the inclusion of $\ln y_{t}$ to allow for non-constant returns to scale.

$$
\ln c_{t}=\ln k^{\prime}+\left(\alpha_{c} / r\right) \ln n_{t-1}+(1-r / r) \ln y_{t}
$$

Stating the identities $\ln k^{\prime} \equiv \beta_{0}, \alpha_{c} / r \equiv \beta_{1},(1-r / r) \equiv \beta_{2}$ and plugging them in A7, we finally obtain equation $A .8$, which is the estimation equation (1) in the text.

$$
\ln c_{t}=\beta_{0}+\beta_{1} \ln n_{t}+\beta_{2} \ln y_{t}
$$

\section{References}

Becker, W. (2003) How to Make Economics the Sexy Social Science, Chronicle of Higher Education, 7 December, pp. B10-B11.

Becker, W. and Watts, M. (eds) (1998) Teaching Economics to Undergraduates: Alternatives to Chalk and Talk, Cheltenham: Edward Elgar.

Becker, W. and Watts, M. (2001a) Teaching Methods in U.S. Undergraduate Economics Courses, Journal of Economic Education, Vol. 32 (3), pp. 269-80. 
Becker W. and Watts, M. (2001b) Teaching Economics at the Start of the 21st Century: Still Chalk-and-talk, The American Economic Review: Papers and Proceedings. Vol. 91 (2) May, pp. 449-51.

Berndt, E. (1991) The Practice of Econometrics: Classical and Contemporary, New York: Addison Wesley.

Biggs, T., Grindle, M. and Shodgrass D. R. (1998) The Informal Sector, Policy Reform, and Structural Transformation in: J. Jenkins (ed.) Beyond the Informal Sector: Including the Excluded in Developing Countries, Sequoia Institute.

Cameron, A. C. and Pravin, K. (2005). Microeconometrics: Methods and Applications. Cambridge, 2007 Reprint.

Daniels, L. and Mead, D. (1998) The Contribution of Small Enterprises to Household and National Income in Kenya, Economic Development and Cultural Change, Vol. 47 (1), October, pp. 45-71.

Dewey, J. (1938) Experience and Education, New York: Collier Books.

Dolan, R. and Stevens, J. L. (2005) Business Conditions and Economic Analysis: An Experiential Learning Programme for Economics Students, Social Science Research Network Electronic Paper Collection at: http://ssrn.com/abstract=735923.

McGoldrick, K. (1998) Service-Learning in Economics: A Detailed Application. Journal of Economic Education, Vol. 24(4), pp. 365-76.

McGoldrick, K. (2002) Using the Theory of Service-Learning as a Tool for Teaching Economic Theory in: K. McGoldrick and A. Ziegert (eds) Putting the Invisible Hand to Work: Concepts and Models for Service-Learning in Economics, Edward Zlotkowski.

Mungaray, A. (2002) Re-engineering Mexican Higher Education toward Economic Development and Quality. The XXI century challenge. Higher Education Policy, Vol. 15 (4), pp.391-9.

Mungaray A. and Sanchez M.D. (2003) The Impact of Service Projects on Micro-Enterprises in Mexican Marginalised Communities in: H. Perold, S. Stroud and M. Sherraden (eds) Service Enquiry: Service in the 21st. Century, The Global Service Institute.

Mungaray, A., Ramírez-Urquidy, M., Texis, M., Ledezma, D. and Ramírez-Angulo, N. (2007) Promoting Learning in Small Entrepreneurs and Higher Education Students Through Service Learning Programmes, International Journal of Business Research, Vol. VII (3), pp. 10-28.

Nowotny, H., Scout, P. and Gibbons, M. (2001) Re-thinking science: knowledge and the public in an age of uncertainty. Cambridge: Polity Press.

Kolb, D. (1976) The Learning Style Inventory: Technical Manual. Boston, MA: McBer.

Kolb, D. (1984) Experiential Learning: Experience as the source of learning and development, Journal of Business Ethics, Vol. 15 (1), pp. 45-57.

Peters, T., McHugh, M.A. and Sendall, P. (2006) The Benefits of Service Learning in Down-turned economy, International Journal of Teaching and Learning in Higher Education. Vol. 18 (2), pp. 131-41.

Rhoads, R. (1997) Community Service and Higher Learning: Exploration of the Caring Self, New York: Sate University of New York Press.

Simmons, K. (2003) Teaching Economics of Poverty Using a Service-Learning Approach, Social Science Research Network Electronic Paper Collection at:

http://ssrn.com/abstract=457201

Stephenson, H. B. (1997) Examining the efficacy of offering Service Learning for credit 
with SIFE and SBI: An Exploratory Study, Journal of Entrepreneurship Education, Vol. 1 (1), pp.1-13.

Stroud, S. (2005) A Global Perspective, in:W. Marshall and M. Porter (eds) The Americorps Experiment and The Future of National Service, Progressive Policy Institute.

Wenger, E. (1998) Communities of Practice: Learning, meaning and identity, Cambridge University Press.

Yates, M. and Yuniss, J. (1999) Promoting Identity development:Ten ideas for school based service learning programmes, in: J. Claus and C. Ogden (eds) Service learning for youth empowerment and social change, New York: Peter Lang.

\section{Contact details}

Authors are faculty members of the School of Economics and International Relations, Universidad Autónoma de Baja California.

Calzada Tecnológico \#14418

Mesa de Otay

Tijuana, Baja California

México.

22390 